\title{
AD-A273 366
}

FINAL REPORT TO THE

OFFICE OF NAVAL RESEARCH

CODE $1121 R F$

WASHINGTON, DC 22117

FROM

WOODS HOLE OCEANOGRAPHIC INSTITUTION

WOODS HOLE, MASSACHUSETTS

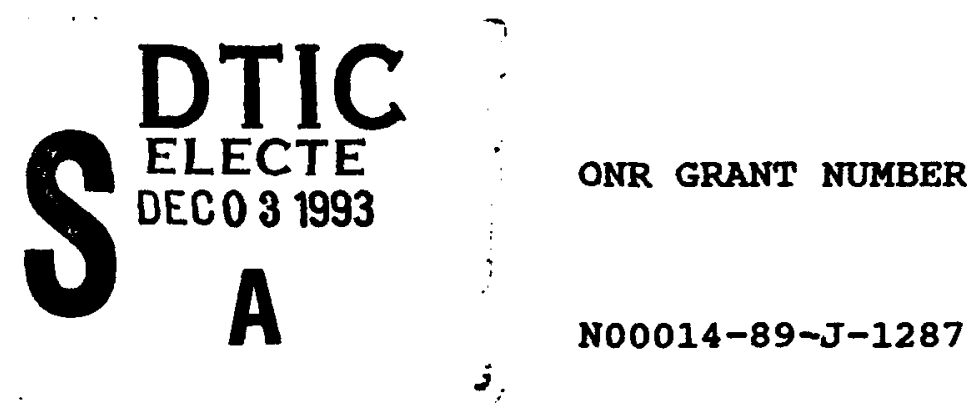

REPLACEMENT OF OBSOLETE SCIENCE WINCH ON

RESEARCH VESSEL

IAORR (AGOR 15)

\section{$\begin{array}{llll}93 & 12 & 2 & 027\end{array}$


Defense Technical Information Center Building 5

Cameron station

Alexandria, VA

22314

Re: N00014-89-J-1287

Dear sir or Madam:

Enclosed please find one (1) copy of the Final Report on the referenced grant submitted to you in compliance with a request from the ONR Area Representative, Boston (MA) Detachment.

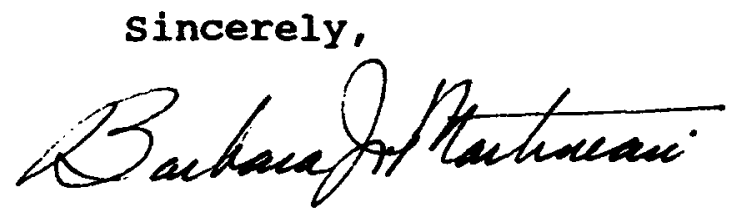

Barbara J. Martineau

Marine Operations Administrator

bm

Encl.

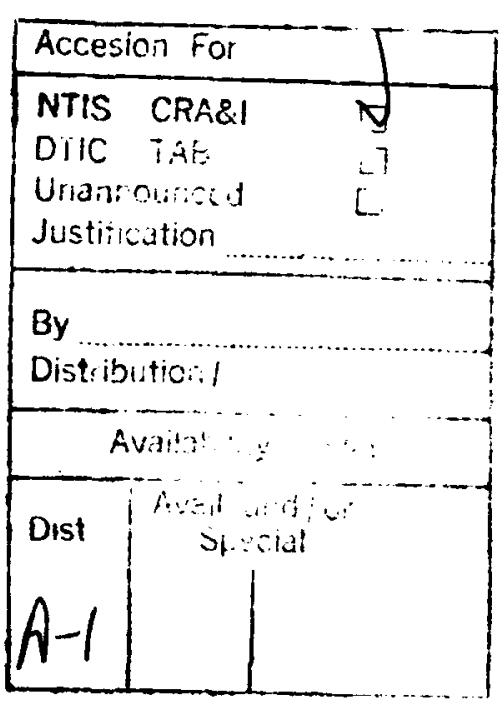


In May 1988 in response to a request for proposal under the Defense University Research Instrument Program, Woods Hole Oceanographic Institution (H.H.O.I.) proposed replacement of two hydrographic winches and the trawl winch on the Research Vessel moRR (AGOR 15). It was proposed that the replacements occur during the mid-life refit and stretch that was then in the planning stages. The Office of Naval Research (ONR) funded the replacement of one winch, and W.H.O.I. elected to replace the Markey DESH-4 hydrographic winch.

Funds from this grant were used to procure a Markey Machinery Co., Inc. Model DESH-5 oceanographic winch. A purchase order was issued in April 1989, and the funds awarded under this grant $(\$ 192,000)$ were consumed by the order. In order to procure a second drum, and install the winch, supplemental funds were required. When the need for the additional funds became apparent, roror was undergoing refit. Additional funds were provided by the refit grant (N00014-89-J-1168) to complete the winch purchase and to provide the Lebus shell for the second arum. This arum allows the vessel to carry on board 9,150 meters of $1 / 4$ " wire rope and 10,000 meters of $0.322^{n}$ electro-mechanical cable (UNors "standard") both wound on drums. This permits the change of wire/cable in an out port without a spooling operation. Normal dock side change time for the drum is 90 minutes using the ship's crane. 
late October 1991 during the final outfitting of the vessel, the winch installation was found to be improperly wired with a potential electrical shock condition existing during operation. The winch installation was rewired by W.H.O.I. personnel to correct the fault.

The winch was run at sea during the test and "shake-down" cruises on KNORR early in 1992 and used during the first ravoRR science cruise, 30 days to the mid-Atlantic Ridge. Extensive atsea tests were made to correct a reoccurring problem with the electronic controls during the transits to a ship yard in April 1992 and to Chile to begin the World Ocean Circulation Experiment (WOCE) Hydrographic Program in the Pacific.

The new winch was used extensively during the wocE program throughout 1992 and into the first quarter of 1993. The winch performed satisfactorily for science throughout the period. However, a severe vibration developed during the later stage of the Pacific cruise. It has been determined that the root cause of the vibration is most likely a failed motor bearing which will be replaced. In addition, the deck on which the winch is mounted is limber, which appears to have significantly magnifed the vibration emanating from the motor. To remove this condition, the deck structure is to be stiffened and strengthened during the next ship yard period utilizing funds (N00014-93-C0164) provided by ONR.

When IrorR returned to Hoods Hole in August 1993 at the completion of a 17 month extended sruise, the winch was removed from the ship and returned to the manufacturer in seattle to 
deck structure is to be stiffened and strengthened during the next ship yard period utilizing funds (No0014-93-C0164) provided by ONR.

When morR returned to Woods Hole in August 1993 at the completion of a 17 month extended cruise, the winch was removed from the ship and returned to the manufacturer in seattle to renew the corrosion protection paint system because the preservation coat had failed prematurely.

The winch shares a common overboarding point to the Hydro Boom with the other hydrographic winch on the ship. The cable leads from the winch through two fixed fairleading sheaves to the overboarding block mounted on the extendible Hydro Boom. All sheaves in the train are a minimum of 20" tread diameter. Sensors for the wire monitoring system are mounted on one of the fixed sheaves.

The winch is controlled from an operator's shack mounted adjacent to the winch on the hangar top. The operator has a clear view of the winch, the sheave train, over the side and the deck work/landing area. The operator has intercom communications with the bridge and laboratories. Winch parameters (line count, line speed and tension) are displayed at the control stand, in the laboratories, and on the bridge. 


\section{Winch specifications and Performance.}

Make:

Model:

Serial Number

Markey Machinery Co., Inc.

DESH 5

15009

Net Weight (with electric motor and brake):

Separate Electrical Components - Net Weight

Rated Drum Capacity

13,050 lbs.

$1,4501 \mathrm{bs}$.

$10,000 \mathrm{~m}$

$0.322^{\prime}$ E.M. Cable

Drum Barrel Diameter (Under Lebus Shell) 18 "

Drum Barrel Iength:

Drum Flange Diameter

Power:

Electric, AC-SCR/DC, 75 hp

Rated Line Pul1:

10,300 Ibs. bare drum

5,926 lbs at $102 \mathrm{~m} / \mathrm{min}$ at mid scope

4,547 Ibs. at $133 \mathrm{~m} / \mathrm{min}$ at full drum

Average Working speed:

Winch Gear Ratio:

$80 \mathrm{~m} / \mathrm{min}$

Input Reduction

Intermediate Reduction

Main Gear Reduction

$85 T / 26 T$

$77 \mathrm{~T} / 28 \mathrm{~T}$

$92 \mathrm{~T} / 27 \mathrm{~T}$

Total Gear Reduction
$3.27: 1$

$2.75: 1$

$3.41: 1$

$30.7: 1$ 
